\section{Global Journal of Foreign Language Teaching}

Volume 7, Issue 2, (2017) 91-100

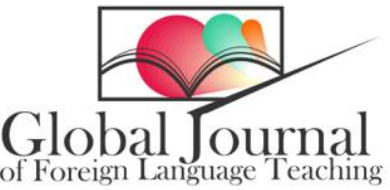

www.giflt.eu

\title{
The effect of peripheral learning on elementary EFL learners' grammar improvement: The case of prepositions of time and place
}

Islam Namazian Doost*, Islamic Azad University, Shahrekord Branch, 166 Shahrekord, Iran.

Soheila Tahmasbi, Islamic Azad University, Abadan Branch, Abadan, Iran.

\section{Suggested Citation:}

Doost, I. N. \& Tahmasbi, S. (2017). The effect of peripheral learning on elementary efl learners' grammar improvement: The case of prepositions of time and place. Global Journal of Foreign Language Teaching. $7(2), 91-100$.

Received from November 02, 2016; revised February 20, 2017; accepted April 23, 2017.

Selection and peer review under responsibility of Assoc. Prof. Dr. Ali Rahimi, Bangkok University, Thailand.

${ }^{\circledR} 2017$ SciencePark Research, Organization \& Counseling. All rights reserved.

\begin{abstract}
This studyaims to inves tiga te the possible effects of peri phe ral learning on elementa ry EFL lea mers' grammarimprovement: the case of prepositions of time and place. Two elementary classes were selected as experimental and control groups. Before beginning the treatment, a grammar test was administered to both the groups as a pre-test. Then, as treatment, the experimental group was exposed to realia, pictures, posters and texts, while the control group was not. After term -long treatment of 10 weeks, the two groups received the same grammar test as post-test. The results of t-test showed that the experimental group improved their gramma rability, i.e., knowledge of prepositions of time and place more than their friends in the control group. The finding of the study mayopen an optional path for teachers to include some peripheral materials in their tea ching envi ronment to further invest on uncons cious lea ming abilities of the students.
\end{abstract}

Keywords: Peripheral learning, re positi on of time, prepositions of place, grammar.

\footnotetext{
* ADDRESS FOR CORRESPONDENCE: Islam Namazian Doost, Islamic Azad Uni versity, Shahrekord Branch, 166 Shahrekord, Iran. E-mail address:e.namazi75@yahoo.com / Tel.: +98 218897
} 
Doost, I. N. \& Tahmasbi, S. (2017). The effect of peripheral learning on elementary efl learners' grammar improvement: The case of prepositions of time and place. Global Journal of Foreign Language Teaching. 7(2), 91-100.

\section{Introduction}

At the core of verbal confrontations on issues, for example, the part of punctuation in dialect educational programmes (Richards \& Rodgers, 2001) and systems for showing dialect abilities and subaptitudes all the more proficiently, are contrasting points of view on the estimation of syntax for the dialect student and contradicting perspectives of what instructive advantages realising linguistic use may possibly accumulate (Myhill \& Watson, 2014). Although such open deliberations on the idea of dialect learning and educating appear to be unending, there are a few features about language structure that most hypotheses share in like manner.

Today, grammar is believed to be the central part of language learning and it has great importance for language learners (Wang, 2010). Words are utilised for naming objects, actions and for conveying tips to others, and without having grammar the intended meaning can't be understood absolutely (Dor, Knight \& Lewis, 2014; Hurford, 2007). Moreover, when we come to leam a new language, we need to study its grammar (Debata, 2013; Thanasoulas, 2001). Without a complete knowledge of grammar, learners' knowledge development will be limited (Richards \& Renandya, 2002).

Despite the mentioned common grounds in the history of language learning and teaching, there have been changes in teaching grammar. Grammar leaming has been viewed as equally central and peripheral in language learning at different periods of time (McNeill, 1970; Rama \& Agullo, 2012; Weaver, McNally \& Moerman, 2001). Once in a while, educators plan to quicken the procedure through which understudies figure out how to utilise an alternate dialect for everyday discussion. For this, a greater amount of the understudies' mental power must be tapped (Larsen-Freeman, 2000). This truly is combined with de-suggesting the mental obstructions and impediments the understudy brings with him or her towards the learning problem and utilising methods to enact the paraconscious part of the brain (Lozanov, 1978).

Suggestopedia, as one of the humanistic approaches created in the 1970s by the Bulgarian instructor Georgi Lozanov, urges understudies to apply dialect all the more autonomously and assume more individual liability for their own learning. As indicated by Lozanov (1978), students may have utilised just $5 \%-10 \%$ of their mental limit, and that the cerebrum could process and hold considerably more material if given 'ideal' conditions for learning. Harmer (2001) states that Suggestopedia considers the physical environment and air of the classroom of crucial significance; moreover, the teachers should 'suggest' whatever students like and 'desuggest' whatever they dislike. Students should eliminate the feelings that they cannot be successful and thus, the teacher helps them overcome the barriers to learning. Moreover, the learner is seen as a person whose physical, emotional and intellectual sides are intertwined (Arnold, 1998; Sucaromana, 2012).

It is generally believed that the more pleasant the environment provided, the more successful and effective are students' learning and achievements (Vodesilova, 2013). Consequently, it is important to make a positive climate and environment where students feel great and safe to learn (Bancroft, 1995). Larsen-Freeman (2003) also stresses that posters showing grammatical data help students to take advantage of peripheral learning. This supports the learners to learn not only from direct instructions but also from the surrounding environment.

Peripheral learning as one of the fundamental principles of Suggestopedia depends on the possibility that we see substantially more in our surroundings than we intentionally see (Bancroft, 1995). The word fringe can be associated with ideas like irrelevant, minor, optional and negligible (Fatemipour, 2013; Mehmet, Burcu \& Bulent, 2012). Understudies can retain data 'easily' when it is seen as a feature of the earth, as opposed to the material 'to be gone to' (Fatemipour, 2013).

When classrooms provide some information at leamers' periphery, the atmosphe re of classrooms is renovated (Larsen-Freeman, 2000).

In this study, the term 'peripheral' indicates everything that often comes about inside the border rather than the core (Lave \& Wenger, 1991). That is, according to Strasburger, Rentschler and Juttner 
(2011), peripheral vision is a part of vision that occurs outside the very centre of the gaze. Besides, fringe learning alludes to a sort of recognition happening certainly and unexpectedly because of consistent presentation to the expanding measure of data (Bahmani, Pazhakh \& Raeesharif, 2012). It is a method for urging understudies to get associated with learning through backhanded procedures.

Extending these highlights of Suggestopedia and peripheral learning to language classrooms, teachers can use posters and decorations to present the target language grammatical points (prepositions), and hence invest in peripheral learning. The term 'preposition', according to the Cambridge International Dictionary of English, refers to words that 'express relationships between people, things, actions, etc.' (Procter, 1995 cited in Galleguillos, 2013). However, these mostly tiny components of language cannot be ignored, as it is also said that 'English uses prepositions more than many other languages, and one preposition often has several different meanings' (Procter, 1995). Prepositions are used ubiquitously by native speakers all time, but it is often difficult for EFL language learners to decide which preposition to use. These 'little words' carry a lot of meaning (Kl asone, 2013). Also, it is difficult to make sense of how to use relational words successfully as the vast majority of them have a couple of particular capacities and there are generally couple of fundamentals to help in picking which relational words to use precisely (Swan, 1988).

\section{Review of Literature}

By the twentieth century, many teaching foreign/second language approaches and methods have appeared; despite the trends in sixteenth to nineteenth centuries that mostly focused on teaching language through grammar, literature and translation (Titone, 1968), the focus was more on utilitarian and interactional qualities as opposed to auxiliary and syntactic attributes of dialect (Richards \& Rodgers, 2014). Suggestopedia, which initially does not concentrate on instructing the structure of remote/second dialect, is one of these techniques that intend to open a dialect to outside students through suggestive educating. This strategy organises the mental and humanistic variables that are inadvertently missed or purposefully overlooked by most outside dialect educating strategies (Schiffler, 1992; Ziad, 2014).

Suggestopedia prescribe a large group of learning needs which Lozanov portrays as a 'science worried about the efficient investigation of the non-rational and additionally non-conscious impacts' (Stevick, 1976, p. 42). Unwinding music, workmanship and learning climate and also the definitive part of the instructor describe the strategy.

For making this casual state in the student and to improve positive recommendation, Suggestopedia makes utilisation of alleviating, cadenced music, an agreeable and unwinding condition, and a connection between the educator and the understudy like the parent-kid relationship (Rohmert, 1996). The understudies' emotions have a vital place. In a chipper and agreeable condition learning is encouraged. Thus classrooms ought to be splendid, beautiful and agreeable. The instructor ought to know that students convey certain mental boundaries with them to the classroom. These boundaries ought to be destroyed by the instructor.

So the real goal of Suggestopedia is to build understudies' mental potential to learn, keeping in mind the end goal to quicken the leaming procedure and enable understudies to utilise the objective dialect for a fruitful correspondence.

During the process of teaching, Suggestopedia properly utilises condition recommendation, figure proposal, action recommendation and self to persuade English instructing. In view of Suggestopedia the learning condition ought to be brilliant and happy, frequently finished with scenes of occasions from the nation of their objective dialect. Besides, the procedure more often than not goes with music and a few amusements to get fruitful in educating and learning (Bancroft, 1978). In this strategy educators normally go about as special ist and security. They ought to be certain and trustable with the goal that their understudies can depend on them and they ought to give a sprightly classroom climate. Then again, understudies ought to be casual and take after instructor's direction (Stevick, 1980). 
Larsen-Freeman (1986, p. 84-86) classified some common techniques closely related to Suggestopedia, including (a) classroom set-up, (b) peripheral learning, (c) positive suggestion, (d) visualisation and (e) choosing a newidentity.

In peripheral learning, students can get data 'easily' when it is seen as a major aspect of the earth, instead of the material 'to be gone to'. A significant setting can help understudies to comprehend the importance of those structures which they have not aced (Lightbown \& Spada, 2003). So as to encourage learning, pictures or designs as cheat sheets, extensive backdrops, photos or representations have dependably been utilised (Harmer, 2001). In Suggestopedia, target structures are exhibited inactively in an alluring and vivid shape which shows structures and ideal models; the blurbs are set up before the structures are accentuated in class (Bancroft, 1995). Along these lines, the structures are learnt incidentally and semi-intentionally. Fringe data can incite understudies to be more trial, and utilise more sources to acquire dialect contribution to learn dialect better. For instance, through taking a gander at the publications on the classroom divider, understudies can make a few sentences utilising the linguistic structure and depict a specific place in an English talking nation.

Maier and Weberova (1994) argue that posters with text that are displayed for a longer period of time drives learner's attention to studying away. Some researchers investigated language courses that integrate peripheral learning and examined the effects of peripheral conditions on vocabulary learning (Badri, Badri \& Badri, 2015; Bahmani et al., 2012), or on learners' writing skills in cyber environments (Rezayousefi Far \& Soltani, 2013), and they have unanimously suggested positive effects of peripheral learning. However, the interplay of preposition learning and peripheral conditions is another issue; moreover, it is important to check whether what researchers have offered as peripheral in the classroom was attracted by the learners.

\section{Research Questions}

The present study seeks to answer the following questions:

1. Is there any significant difference between Iranian elementary EFL learners' knowledge of prepositions of time and place under peripheral and non-peripheral conditions?

2. Do Iranian elementary EFL leamers make any connections between the peripheral conditions in classroom and their ability to answer related questions?

\section{Methodology}

\subsection{Participants}

This work was conducted on 40 elementary EFL learners from Parsian Language Institute in Ahvaz, 
Doost, I. N. \& Tahmasbi, S. (2017). The effect of peripheral learning on elementary efl learners' grammar improvement: The case of prepositions of time and place. Global Journal of Foreign Language Teaching. 7(2), 91-100.

\subsection{Instruments}

\subsubsection{A teacher-made grammar test}

A teacher-made grammar test based on students' source book 'Connect Book I' by, Richards, Barbisan and Sandy (2009) was developed (Appendix A). At the beginning, the participants were pretested using the teacher-made grammar test which aimed to measure the students' knowledge of preposition. It included two parts: One part was a cloze test which consisted of 20 blanks. For each blank there were four choices and the students had to choose the appropriate word for each blank. The cloze test included a mixture of target structure items and distracter items; these items were prepared to particularly check students' knowledge of prepositions of time and place - in, on, at. It should be mentioned that the researcher taught other English prepositions of time and place in the classroom but he considered three prepositions - in, on, at - due to some reasons: They are more problematic and students may confuse to distinguish them from each other (Abkhoo, Gorjian \& Pazhakh, 2014; Boquist, 2009; Galleguillos, 2013). Moreover, these three prepositions are more emphasised in the students' course book; furthermore, as the students are at elementary levels of learning, these prepositions match their proficiency level comparing with other complex prepositions. The test also embraced items on other grammatical points such as: to be verbs, a/an, do/does, thirdperson singular, etc. which were among the required grammatical points students were to leam during the present term of study. The second part of the test included 20 multiple choice items (10 target structure items and 10 distracter items) and asked the learners to choose the correct choice.

Toward the finish of the investigation, to discover about the conceivable impacts of the peripheral conditions on the understudies' punctuation change, this test was utilised once more. Truth be told, a similar sentence structure test was utilised twice in this examination, once as a pre-test and once as a post-test instrument. All attributes of the post-test were the same as those of the pre-test regarding time and the quantity of things.

The only difference of this test from the pre-test was that the order of questions and alternatives which was changed to wipe out the probable recall effects.

The said test got some unwavering quality and legitimacy measures. After development, it was analysed by ten specialists for its face and substance legitimacy. That is, to get beyond any doubt about the Content validity index (CVI) of the test things, ten educators who likewise showed English for over 5 years read through the tests and rolled out a few improvements with respect to the lucidity, straightforwardness and the representativeness of things. In this way, the test was adjusted and after that guided on a comparative gathering in another organisation whose course book and level were the same. Subsequent to applying approval and guiding, the fundamental alterations were taken after. Thing office, thing segregation, and decision dispersion were checked. Five things were viewed as improper and overlooked. At last, 40 things were chosen for the last form of the test. The dependability of the pre-test and post-test was registered through the utilisation of Kuder and Richardson (KR-21) equation and estimations of 0.86 and 80.6 were gotten separately. The al located time was 40 minutes and the right response to everything got one point. There was no punishment for false reactions. This punctuation test was fundamentally used to discover answers to the main inquiry of the examination. To answer the second inquiry of the investigation, a poll was more appropriate.

\subsubsection{Posters and pictures}

The next instrument used in the present study was some realia including posters and pictures containing the selected grammatical points.

\subsubsection{An open-ended questionnaire}

The questionnaire included 12 open-ended survey questions, which was an adapted form of Williams' (2006) and Ndongo' (2001-2002). The questionnaire mostly asked students to mention if 
they made any connections between the peripheral conditions in the classroom - using pictures and posters - and their abilities in answering related questions in the post-test. It was given to the students when the post-test was administered. Just the students in the experimental group received and filled in this questionnaire.

The questionnaire's validity and reliability had already been studied, however, since the original questionnaire received some changes to meet the purpose of this study, the researcher followed the same steps adopted for validating grammar test to get sure about the validity of the instrument, too. He modified questionnaire received the views English teachers who were familiar with the concept of second language leaming and peripheral learning. There was a general consensus among them concerning the content validity of the questionnaire; as three items out of 15 were eliminated and 12 remained. Moreover, using Cronbach's Alpha test a reliability of 0.893 was found. The obtained questionnaire was given to the participants when participants received the scores of the post-test.

As the participants were elementary language learners and they might have problems to express their views in English, the questionnaire was translated into Persian, and the students were asked to write their views in Persian. To check for the accuracy of the translation, it was then back-translated by the same language teachers who provided their views about CVI of the questionnaire. The questionnaire was specifically developed to gather information to answer the second questions of this study.

\subsubsection{Procedure}

The pre-test checked the members' learning of sentence structure in the two gatherings regarding the linguistic focuses that would have been introduced in 20 sessions of the classroom (three months, 10 weeks, and every week two 70'-sessions).

Afterwards, the experimental group was incidentally exposed to some grammatical points in the posters and pictures and the control group, on the other hand, the control group was engaged in the ordinary programme of the classroom.

Finally, to guarantee the viability of directions and to survey students' syntactic learning of the objective dialect all through the examination, the language structure test was rehashed toward the finish of the test, thus called post-test in the present investigation. Likewise, subjective information were additionally acquired from a study poll including twelve open-finished study things which were shaped to answer the second inquiry of the examination.

\section{Results and Discussion}

Using statistical package for the social sciences version 22, the researchers relied on the results of Kolmogorov-Smirnov test which suggested a significance level larger than 0.05 .

In order to test the hypothesis of the study, t-test was utilised to compare the means of the experimental and control groups on the two administration of the teacher made test: the pre-test administration and the post-test administration (Tables 1 and 2).

\subsection{Participants' performance on pre-test}

Table 1. T-test results for groups' performances on pre-test

\begin{tabular}{|c|c|c|c|c|c|c|c|}
\hline Groups & $N$ & Mean & SD & $\begin{array}{c}\text { Mean } \\
\text { difference }\end{array}$ & T-value & $d f$ & Sig. \\
\hline Experimental & 20 & 14.85 & 1.59 & 0.45 & 0.79 & 38 & 0.43 \\
\hline Control & 20 & 14.40 & 1.98 & & & & \\
\hline
\end{tabular}


Doost, I. N. \& Tahmasbi, S. (2017). The effect of peripheral learning on elementary efl learners' grammar improvement: The case of prepositions of time and place. Global Journal of Foreign Language Teaching. 7(2), 91-100.

As can be seen from Table 1 , the observed t was computed to be 0.790 . In other words, the difference between the means of the both experimental and control group performances (14.40 vs. 14.85 respectively) were not significant as $p$ is 0.43 .

\subsection{Participants' performance on post-test}

Table 2. T-test results for group' performances on post-test

\begin{tabular}{lccccccc}
\hline \multicolumn{1}{c}{ Groups } & $N$ & Mean & SD & $\begin{array}{c}\text { Mean } \\
\text { difference }\end{array}$ & T-value & df & Sig. \\
\hline Experimental & 20 & 36.95 & 1.46 & 8.45 & 16.47 & 38 & 0.00 \\
Control & 20 & 28.50 & 1.76 & & & & \\
\hline
\end{tabular}

Looking at the exhibitions of the two gatherings on post-test, the consequences of t-test $p$ esteem of.00 which is littler than the hugeness level set for the examination (0.05), henceforth an importance contrast is recommended. As the post-test mean of trial bunch was 8.45 scores higher than post-test mean of control gathering, one might say that fringe conditions in the trial aggregate decidedly influenced the trial gathering's execution on relational words. To further check the Intra group changes paired t-test was used (Tables 3 and 4).

Table 3. Paired t-test of control group

\begin{tabular}{ccccccc}
\hline $\begin{array}{c}\text { Control } \\
\text { group }\end{array}$ & $N$ & Mean & SD & $\begin{array}{c}\text { Mean } \\
\text { difference }\end{array}$ & T-value & df \\
\hline Pre-test & 20 & 14.40 & 1.98 & -14.10 & -21.09 & 19 \\
Post-test & 20 & 28.50 & 1.76 & & & \\
\hline
\end{tabular}

Table 4. Paired t-test of experimental group

\begin{tabular}{lcccccc}
\hline $\begin{array}{c}\text { Experimental } \\
\text { group }\end{array}$ & $N$ & Mean & SD & $\begin{array}{c}\text { Mean } \\
\text { difference }\end{array}$ & T-value & df \\
\hline Pre-test & 20 & 14.85 & 1.59 & -22.10 & -51.5619 & \\
Post-test & 20 & 36.95 & 1.46 & & & \\
\hline
\end{tabular}

According to Table 3, it is observed that t-value was -21.093 , while t-critical with 19 degrees of freedom for 0.05 level, showed $t$-critical of 2.0930. As the $t$-value was smaller than the $t$-critical $(-21.093<2.0930)$, it is suggested that the difference between the pre-and the post-test in the control group was not significant enough.

On the other hand, in Table 4 the $\mathrm{t}$-value is -51.565 , which is smaller than the $\mathrm{t}$-critical $(-51.565<$ 2.0930), this result in turn suggest that the experimental group performed better on their post-test.

\section{Questionnaire}

Firstly, to test the reliability of the questionnaire, Cronbach's alpha analysis was performed, and, according to Farhady (1995), the results $(r=0.893)$ indicated that the questionnaire had a satisfactory level of reliability.

Based on students' answer to all 12 questions, the following results were obtained: 
Doost, I. N. \& Tahmasbi, S. (2017). The effect of peripheral learning on elementary efl learners' grammar improvement: The case of prepositions of time and place. Global Journal of Foreign Language Teaching. 7(2), 91-100.

1) Pictures and posters with text on the wall helped students to perform better in the post-test

2) Pictures and posters on the wall motivated students to study more and they were good for their moods

3) Students prefer to learn grammar through visual aids

4) Students could leam better if the teacher hang the grammatical points on the wall through pictures and posters

5) Students preferred a decorated class full of interesting pictures and posters with text on the wall instead of a simple common class.

Taken in general, if proper condition and materials are set up for students, fringe learning of sentence structure is probably going to take the floor more unequivocally than some time recently. Thusly in noting the examination inquiries of the investigation it can be kept up that the outcomes affirmed the adequacy of fringe learning alongside deliberate one. That is, by putting notices containing dialect highlights and syntactic data about the objective dialect on the classroom dividers, understudies will retain the essential actualities easily. At the point when the understudies are effective in doing self-exercises, they will be more certain, as well.

\section{Discussion}

The answer to the first question of the study which asked 'is there any significant difference between Iranian elementary EFL learners' knowledge of prepositions of time and place under peripheral and non-peripheral conditions?' could be yes. The results of Table 2, suggested a significance level of .000 which in turn indicate a meaningful difference between the performances of the two groups.

With regard to research question 2, the experimental group' answers to the questionnaire were analysed. Based on the results obtained, the majority of students preferred a peripheral learning climate because it helped them enhance their knowledge of prepositions of time and place. Moreover, 95\% learners approved that pictures and posters with text on the wall helped them to perform better in the post-test. Although it may seem as an irony that what was suggested as periphery was noticed by the students (about 95\%), this fact may point to other issues. As most language classrooms in Iran have bare walls and the only medium of learning are teachers and books, what was put on the walls was saliently noticed by the learners.

\section{Conclusion}

This study started with the presumption that applying peripheral learning strategy could enhance the Iranian elementary EFL learners' grammar improvement. The experimental group were taught grammar, i.e., prepositions of time and place through pictures and posters that contained grammatical points pasted on the walls of the classroom.

The findings of this study may be effective for EFL instructors to integrate the tenets of peripheral learning in their teaching to help learners enhance their grammar and vocabulary. Also, the discoveries of this investigation is productive for EFL students, as they can make utilisation of the fringe of the classroom conditions as an instructive device, remember the gained information, utilise their engaged consideration and in addition their fringe consideration, enhance their self-learning capacity, upgrade self-sufficiency, certainty and motivation (Kuo, Yu \& Hsiao, 2014; Taylor, 1990). Besides, the discoveries of this investigation recommend that EFL students need to assume greater liability for their learning and depend less on educators and contribute on what is inside their fringe get to. On the off chance that students are exclusively and totally reliant on their educators, when they are left without anyone else's input, they effectively quit learning. Fringe leaming as a Strategy is a valuable approach to wipe out this issue. In dialect showing Learners' self-sufficiency is a definitive objective. By Learners' self-rule it implies that without dialect instructors and classes, dialect students 
Doost, I. N. \& Tahmasbi, S. (2017). The effect of peripheral learning on elementary efl learners' grammar improvement: The case of prepositions of time and place. Global Journal of Foreign Language Teaching. 7(2), 91-100.

proceed with their learning. Therefore, students are additionally prescribed to get comfortable with inventive linguistic use showing systems, particularly fringe leaming and its basic standards so as to profit by its focal points.

\section{Reference}

Abkhoo, F., Gorjian, B. \& Pazhakh, A. (2014). Teaching spatial and temporal prepositions through audio, pictorial speech, and video modalities to pre-intermediate EFL learners. International Journal of Language Learning and Applied Linguistics World, 5(1), 441-457.

Arnold, J. (1998). Towards more humanistic English teaching. ELT Journal, 53(3), 235-242.

Badri, A., Badri, A. \& Badri, G. (2015). The effects of peripheral teaching on Iranian EFL vocabulary improvement. International Journal of Educational Investigations, 2(1), 10-18.

Bahmani, M., Pazhakh, A. \& Raeesharif, M. (2012). The effect of peripheral learning on vocabulary acquisition, retention and recall among Iranian EFL learners. Higher Education of Social Science, 3(1), 44-52.

Bancroft, W. (1978). The Iozanov method and its American adaptations. The Modern Language Journal, 62(4), 167-175.

Bancroft, W. J. (1995). 
Doost, I. N. \& Tahmasbi, S. (2017). The effect of peripheral learning on elementary efl learners' grammar improvement: The case of prepositions of time and place. Global Journal of Foreign Language Teaching. 7(2), 91-100.

Rama, J. L. \& Agullo, G. L. (2012). The role of grammar teaching: from communicative approaches to common European framework of reference for languages. Revista de Lingyistica y Lenguas, 7, 180-199.

Rezayousefi Far, S. \& Soltani, R. (2013). The effects of peripheral teaching on Iranian EFL learners' writing skill in cyber environments. International Journal of Language Learning and Applied Linguistics World, 3(3), $112-121$.

Richards, J. \& Renandya, W. A. (2002). Methodology in language teaching. Cambridge, UK: Cambridge University Press.

Richards, J. \& Rodgers, T. (2014). Approaches and methods in language teaching. Cambridge, UK: Cambridge University Press.

Richards, J. C., Barbisan, C. \& Sandy, C. (2009). Student's book. Ca mbridge, UK: Cambridge University Press.

Richard, J. C. \& Rodgers, T. (2001). Approaches and methods in language teaching. Cambridge, UK: Cambridge University Press.

Rohmert, A. (1996). Teaching and learning in new dimensions. Paper presented at Modern Foreign Language Conference. Access Date: 01 December 2016. http://www.paul-raedle.de/vtrain/sugg.htm

Schiffler, L. (1992). Suggestopedic methods and applications. London, UK: Routledge.

Stevick, E. W. (1976). Memory, meaning and method: Some psychological per-spectiues on language leaning. Rowley, MA: Newbury House.

Stevick, E. W. (1980). Teaching languages: A way and ways. Rowley, MA: Newbury House.

Strasburger, H., Rentschler, I. \& Juttner, M. (2011). Peripheral vision and pattern recognition: A review. Journal of Vision, 11(13).

Sucaromana, U. (2012). Contribution to language teaching and learning: A review of emotional intelligence. English Language Teaching, 5(9), 54-58.

Swan, M. (1988). Practical english usage. Oxford, UK: Oxford University Press.

Taylor, E. (1988). Subliminal learning: An eclectic approach. Boulder City, NV: RK Book.

Thanasoulas, D. (2001). The importance of teaching culture in the foreign language classroom. Radical Pedagogy, ICCAP. Access Date: 01 December 2016. http://radicalpedagogy.icaap.org/content/issue3 3/7thanasoulas.html

Titone, R. (1968). Teaching foreign languages: An historical sketch. Washington DC: Georgetown University Press.

Wang, S. (2010). The significance of English grammar to middle school students in China. Journal of Language Teaching and Research, 1(3), 313-319.

Weaver, C., McNally, C. \& Moerman, S. (2001). To grammar or not to grammar: That is not the question! Voices from the Middle, 8(3), 17-33.

Williams, B. (2006). Creative use of technology to optimize peripheral learning (CPR Learning Space). Cornwall, UK: University of Newcastle Upon Tyne.

Ziad, M. A. (2014). Using suggestopedia in ELT in Saudi Arabia: Implications for pedagogy. Access Date: 01 December 2016. http://dx.doi.org/10.15242/ICEHM.ED1214088 